\title{
Psychological Ways of Understanding Textual Reality of the Novel
}

\section{Психологічні шляхи розуміння текстової реальності}

\author{
Nataliia Mykhalchuk \\ Dr. in Psychology, Professor, Rivne State University of the \\ Humanities, Rivne (Ukraine) \\ ORCID ID: https://orcid.org/0000-0003-0492-9450 \\ Researcher ID: http://www.researcherid.com/rid/A-9440-2019 \\ Scopus ID: 57214227898 \\ E-mail: natasha1273@ukr.net
}

\section{Наталія Михальчук}

Доктор психологічних наук, професор, Рівненський державний гуманітарний університет, м. Рівне (Україна)

\section{Iryna Koval}

Ph.D. in Psychology, Assistant Professor, Assistant Professor of the Department of Foreign Language Education and Intercultural Communication, Khmelnytskyi National University, Khmelnytskyi (Ukraine)

ORCID ID: https://orcid.org/0000-0002-2048-0000

Researcher ID: http://www.researcherid.com/rid/B-2173-2019

E-mail: iryna-koval@i.ua

\section{Ірина Коваль}

Кандидат психологічних наук, доцент, доцент кафедри іншомовної освіти і міжкультурної комунікації, Хмельницький національний університет, м. Хмельницький (Україна)

Address for correspondence, e-mail: kpnu_lab_ps@ukr.net Copyright: (C) Mykhalchuk Nataliia, Koval Iryna



The article is licensed under CC BY-NC 4.0 International (https://creativecommons.org/licenses/by-nc/4.0/)

DOI (article): https://doi.org/10.32626/2227-6246.2021-54.93-115

(C) Mykhalchuk Nataliia, Koval Iryna 
DOI: https://doi.org/10.32626/2227-6246.2021-54

2021. випуск 54

The contribution of the author: Mykhalchuk N. $-50 \%$, Koval I. $-50 \%$.

Авторський внесок: Михальчук Н. $-50 \%$, Коваль І. $-50 \%$.

\section{ABSTRACT}

The aim of the research is to examine the most important features of Charles Dickens' individual style of writing and the characteristics of students' understanding of Charles Dickens, the effect produced by the language expressive means and stylistic devices in the authors' texts of students.

Methods of the research. The following theoretical methods of the research were used to solve the tasks formulated in the article: a categorical method, structural and functional methods, the methods of the analysis, systematization, modeling, generalization. The experimental method is the method of interview.

The results of the research. We note that every novel is a cultural phenomenon. The global question what makes a novel "cultural» is that it is not the speech information itself that describes the "passive and voiceless» object of a particular study, but the fact that the novel is the text of another, dissimilar to our consciousness. When we are dealing with the author, with his personal worldview and the meaning that appears in the text is relevant. There is nothing in the culture but meanings and means of their transmission. The novel is a phenomenon of a certain culture and, as a result, can be considered as a «meaningful world». During the "meeting" of the person with the work, our own understanding of life will be included into the situation of cultural communication with the author. The personal meanings of the recipient and the author's one are always dissimilar, even completely dissimilar, sometimes strikingly different from each other. This, of course, in some a way complicates the process of understanding a novel, but this discrepancy influences on its understanding. Scholars consider a novel to be a piece of another consciousness, the understanding of which inevitably turns into a dialogue, a "meeting in a meaningful world».

We recognize the main characteristic of a novel as its dialogic nature, emphasizing two-dimensional existence of the text. We think that each text has its subject, the author. Also there is another plan of the text-another subject, which reproduces someone another text and creates so called outlined text (commented, evaluated, denied). We'd like to emphasize the complexity of the relationships between these two plans, because they create a «meeting» of two texts - the completed structure and some text that can be created; it is a meeting of two consciousnesses, two authors. That is why, the dialogical nature of a no(c) Mykhalchuk Nataliia, Koval Iryna

DOI (article): https://doi.org/10.32626/2227-6246.2021-54.93-115 
vel directs the author's position, the author's "voice» to the reader, who agrees or disagrees, asks, answers or not, also denies.

Conclusions. Therefore, we can be argue that a novel is understood as the implementation of a system, as a lexical and syntactical formation, which contains signs of natural language, which has been defined by the author with the help of boundaries and internal semiotic organization. The latter at the syntagmatic level turns the text into a structural whole. The basis of a novel is its output in other texts, pieces of art, the presence of such characteristics as communicative orientation.

We also believe that any novel is dialogical in its internal structure, because it contains both real and hidden appeals to some authors, directed against the views of other authors. If a non-dialogical text is possible it would be meaningless or would take on a form that can be given any meaning that is practically the same.

Key words: understanding textual reality, dialogical text, non-dialogical text, individual style of writing, communicative orientation, internal semiotic organization, cultural communication with the author.

\section{Introduction}

The idea of psychological ways of understanding textual reality of the novel intersects with the views of scientists, who write that the novel is a certain stable model of the world, a certain informative message, created in the language of art, which does not exist outside of all other means of social communication (Brédart, 1991; Терновик \& Сімко, 2020). The text has its complex meaning in the internal structure, according to it semiotic formation, a complex system of meanings, which are, in turn, due to the artistic structure of the novel. Scientists (Гончарук \& Онуфрієва, 2018) believe that the text is not only a communicative, but, above all, a semiotic formation. Because of it semiotic structure, implemented by means of linguistic semantics, the text encodes information about non-textual reality in the text, then outlines the communicative structure with the aim of connecting the structure of linguistic semantics with the real conditions of some communi-

(C) Mykhalchuk Nataliia, Koval Iryna DOI (article): https://doi.org/10.32626/2227-6246.2021-54.93-115 
DOI: https://doi.org/10.32626/2227-6246.2021-54

2021. випуск 54

cative act of the author and the reader. Only as a result of the existence of this connection any linguistic sequence becomes the informative statement (as it is a novel). The action of the semiotic mechanism determines the structure of the text, its internal coherence and semantics, the action of the communicative mechanism - its semantic saturation.

Each case of the actualization of the author's means in order to give them a certain meaning performs both a local function and a general finished text. In this sense, the effect of the language in the literary text can be compared with a pyramid, the top of which is a formulated concept in the whole, the basis of the text is displayed by numerous contextual inclusions. Combining by their local functions into ever larger formations, they gradually form a concept. In novels of a large form, obviously, there are several "pyramids» of such a type, which, in turn, have been hierarchically organized set structure, the basic, main, global concept of a novel.

Some scientists (Cilibrasi, Stojanovik, Riddell \& Saddy, 2019) according to the dual nature of the text echoes the opinion that the truth of the novel is, above all, its historical sense or historical meaning. "Historical meaning", in turn, is the result of intentionality. The intention seems to strain the text internally, creates its stable semantic structure, which is fixed by a system of characters in the paradigm and syntagmatics of the plot. To understand the "historical meaning" means to understand the structure of the novel, to realize the world of the author through the text, to experience its emotional level, the expression of life was built-in the text. In addition to the understanding of the text's «historical meaning", it includes many transhistorical meanings, which should not be reconstructed, but created by the reader. In order to penetrate into the deep essence of the novel, it is not enough to look at or even to read it. To understand transistorical meanings, it is not enough to understand only the semantics of the text and factual information, but to analyze the author's position, to (C) Mykhalchuk Nataliia, Koval Iryna

DOI (article): https://doi.org/10.32626/2227-6246.2021-54.93-115 
DOI: https://doi.org/10.32626/2227-6246.2021-54

2021. випуск 54

build the person's own opinion, to make his/her own points of view orientated on real events, based on those signals, instructions, inclusions with the purpose to carry components of the text.

Thus, the basis of the text is not its closed internal structure, but the transcendent existence to other texts, already having been formed fixed codes. From a semiotic point of view, a novel has the following characteristics:

1. Certainty. The essence of this characteristic is that the novel is fixed within the corresponding signs and thus it is opposed to all other non-textual structures. For fiction, such certainty of the text is provided by the signs of so called «natural language». This allows us to understand the text as the implementation of a certain language system, some material structure.

2. Delimitation. The text is opposed, on the one hand, to all materially created signs which are not part of it, by the principle of inclusion-non-inclusion, and on the other hand by understanding of all its structures that do not have clear boundaries.

3. Structureness. The text is characterized by its internal organization, which transforms it on a syntagmatic level into a structural whole. In order to distinguish a certain set of phrases, statements, being recognized as a novel, one should make sure that these set characteristics make a secondary structure at the level of artistic organization of the text. Thus, a novel is built as a special organization of its lexical units (Mykhalchuk \& Bihunova, 2019).

We think that on the understanding of the novel in a great degree the individual style of the author's writing is influenced. The style of a piece of writing is the way in which features of the language are used to convey meaning, typically but not always within the constraints of more widely accepted conventions of Grammar and Spelling.

(C) Mykhalchuk Nataliia, Koval Iryna DOI (article): https://doi.org/10.32626/2227-6246.2021-54.93-115 
DOI: https://doi.org/10.32626/2227-6246.2021-54

2021. випУск 54

All novels have some style, even if the author does not think about it. It is important to understand that style reflects meaning. For instance, if a writer wants to express the sense of euphoria, he might write by a style which is connected with expressive modifiers. Some writers use styles which are very specific, for example to pursuit the artistic effect.

In spite of a large number of definitions of the term «style», we think, that they all can be divided into three groups. The antique and medieval rhetoric defines the style as a special form of statements, often of oratorical art, understanding by its functions. The second group of definitions determines style as the expression of individual experience. And, finally, the third group of definitions explains style from the functional point of view.

The word "style» is derived from the Latin word «stilus», which is meant a short stick having been sharp from the first side and it is flat from the other one. The word «stilus» is used by the Romans for writing on wax tablets. Now the word «style» is used in so many senses that it has become a breeding ground for ambiguity. The word is applied for the process of teaching, for example how to write a composition; it is also used to reveal the correspondence between a thought and the expression; it frequently denotes an individual manner of making use of language; it sometimes refers to more general, abstract notions thus inevitably becoming vague and obscure, as, for example, «style is the man himself», "style is depth», "style is deviations», "style is choice» (Тлумачний словник, 2021).

All these ideas directly or indirectly bear on issues in stylistics. Some of them become very useful by revealing the springs which make our utterances more emphatic, effective and goal-directed. It will therefore not come amiss to quote certain interesting observations regarding style having been made by different writers from different points of view. Some of these observations are understood by us as epigrams or sententious. Here are some more of them.

C Mykhalchuk Nataliia, Koval Iryna

DOI (article): https://doi.org/10.32626/2227-6246.2021-54.93-115 
DOI: https://doi.org/10.32626/2227-6246.2021-54

2021. випуск 54

Some scientists consider the style as a quality of language which communicates precisely by emotions or thoughts, or a system of emotions or thoughts, peculiar to this author. They also name the specific feature of the style: a true idiosyncrasy of a style as the result of the author's success in compelling language to be conformed to his/her mode of experience (Crookes, 1989).

Some other scientists define style in such a way: «Style is a contextually restricted linguistic variation", "style is a selection of non-distinctive features of the language», "style is simply synonymous with the form or expressions and the hence as a superfluous term", "style is essentially a situational process, a body of formulae, a memory (almost from the cybernetic sense of the word), a cultural and not expressive inheritance» (Тлумачний словник «Multitran», 2021).

Summarising all these definitions we can definitely say that every mentioned statement explains a style as a special feature, which any writer can characterise.

We consider that the word "style» as the subject of linguistic stylistics is confined to the study of the effects of the message, its impact on the reader. Thus we think that stylistics will be a branch of General linguistics by the effects of the message, of its output of the act of communication, of its attention-compelling function. This point of view has clearly been reached under the influence of recent developments in the paradigm of general theory of information. The language, having been one of the means of communication or, to be exact, the most important means of communication, it is understood from a pragmatic point of view. Stylistics in that case has the meaning as a language science, which deals with the results of the act of communication.

Our definition of style is most frequently applied in contemporary Stylistics. We think, that style is a product of individual choices and patterns of choices (emphasis added) among some linguistic possibilities. This definition indirectly deals

(C) Mykhalchuk Nataliia, Koval Iryna DOI (article): https://doi.org/10.32626/2227-6246.2021-54.93-115 
DOI: https://doi.org/10.32626/2227-6246.2021-54

2021. випуск 54

with the idiosyncrasies peculiar to some writer. Somehow it fails to embrace such phenomena into the text structure where the component «individual» is reduced to the minimum or even done away with entirely emphases (giving preference to non-individualistic forms in using language means). However, this definition is acceptable when we apply to the ways menof-letters use of the language of text material when we seek to make it conform to our immediate aims and purposes. Somewhat broader view of style is expressed by us when we maintain that a style may be said to be characterized by a pattern of recurrent selections from the inventory of optional features of the language. Various types of selection can be found by complete exclusion of the optional element, by obligatory inclusion of a feature which is optional elsewhere, varying degrees of inclusion of a specific variant without complete elimination of other competing features (Максименко, Ткач, Литвинчук \& Онуфрієва, 2019).

The idea of taking into account various types of selection as criteria for distinguishing styles seems to be a sound one. It places the whole problem on a solid foundation of objective criteria, such as the interdependence of optional and obligatory features.

Style is understood by us as something that belongs exclusively to the plan of the expressions and not to the plan of the content. This opinion predominantly deals with the correspondence between the intentions of the writer whoever he may be - a man of letters, the writer of a diplomatic documents, the articles in a newspaper or a scientific treatise - and the effect of understanding has been achieved. The evaluation is also based on whether the choice of the language means conforms with the most general patterns of the given type of text - a novel, a poem, a letter, a document, an article, an essay and so on.

It follows then the term «style», being ambiguous, needs a restricting adjective which denotes what particular aspect of C Mykhalchuk Nataliia, Koval Iryna

DOI (article): https://doi.org/10.32626/2227-6246.2021-54.93-115 
style we intend to deal with. It is suggested here that the term «individual style» should be applied to that sphere of Psychology which deals with the peculiarities of the writer's individual manner of using language means to achieve the effect he/ she desires. Deliberate choice has to be distinguished from a habitual idiosyncrasy in the use of language units; each person has his/her own manner and habits of using stylistic means, the speech of an individual which is characterized by peculiarities which are typical, and such particular characteristics are called «the idiolect». The idiolect should be distinguished from what we call "the individual style», as much as the word «style» presupposes a deliberate choice.

So, the idiolects are those qualities of speech which are inherent and which reveal a man's breeding, education, social position, etc. All these factors are, however, undoubtedly interwoven with the individual style. A man's breeding and education will always affect his/her points of view and therefore will naturally be revealed in his/her speech and writing. But a writer with a genuine individual style will be as much as it is possible avoid those language peculiarities which point out to his/her breeding and education in order to leave room for that deliberate choice of language means which will secure the effect sought.

In such a way the individual style of a writer is marked by its uniqueness. It can be recognized by the specific and peculiar combination of language media and stylistic devices which in their interaction present a certain system. This system derives its origin from the creative spirit, and provide elusive though that can be seemed. So, it can nevertheless be ascertained. Naturally, the individual style of a writer will never be in-likely independent by understanding the literary norms in the given period. When we read novels of some authors we can easily detect features which are common to both writers. These features are conditioned by general literary characteristics of some period and they cannot therefore be neglected. In

(C) Mykhalchuk Nataliia, Koval Iryna DOI (article): https://doi.org/10.32626/2227-6246.2021-54.93-115 
DOI: https://doi.org/10.32626/2227-6246.2021-54

2021. випуск 54

this case the adaptations of these canons will always be peculiar and therefore distinguishable. In this case the style of a writer is so closely connected with the content of his/her soul, that the author according his/her experience can see the soul through his/her style, and by studying the form of the text which is penetrated to the depth of the content. The idea of this subtle remark can be interpreted in a following way: the style of a writer can be ascertained only by analysis of the form of a text or by language media. To analyse the form in order to discover the idiosyncrasies of a writer's style is not easy, but a rewarding task. Different approaches to identify the components of individuality are such, as: 1) the composition of larger-than-the-sentence units; 2) the rhythm and the melody of utterances; 3) the system of imagery; 4) the preferences for definite stylistic devices and their co-relation with neutral language media; 5) the interdependence of the language media having been employed by the author and the media characteristics of the personages, which are indispensable (Mykhalchuk \& Ivashkevych, 2019).

The author's Style is the manner in which a writer addresses a matter of fact. A style reveals the writer's personality or his/her own voice. It is the result of choices the writer makes the notes in some syntactical structures, in some paradigm and by figures of thoughts.

Also to distinguish the understanding the writer needs to know who the readers are. This dictates the differences in occupational style having been noted above, but also constrains a style within the occupation or setting. The author needs to follow the next points:

- using excessively a complex language when the text includes implicit acts of communication, but using excessively a simple language when writing for a knowledgeable audience will seem condescending;

- spending time explaining for readers things some already having been known to make them to lose interest. In C Mykhalchuk Nataliia, Koval Iryna

DOI (article): https://doi.org/10.32626/2227-6246.2021-54.93-115 
this case the writer should write in a manner that assumes the audience to be knowledgeable to a certain degree by the given subject.

In such a way the language of a writer is understood by us as a main component as alien to linguo-stylistics. So, the language of a writer can hardly be considered as an object of linguo-stylistics. If it was analysed outside the problem of a style (the style of the text, the writer, the literary trend or the literary era), the language falls into a mass of words, collocations and Grammatical facts, which are taken in isolation. This situation will be understood as some unreliable evidence as to the life of the given language in the given period of its development.

However, our observations of the ways of understanding the language means are employed by different writers, provided no claim which is made to define the individual style as a whole. All this may greatly contribute to the investigation of the ontological nature of these means by throwing light on their potentialities and different ways of functioning. The individuality of the writer's style is shown in a peculiar treatment of using language means.

In this connection it is worth referring to understanding the style as non-personal objectivity, its merits being dependent by the power of thoughts and by the acuteness of the writer's perceptions. The same idea, only slightly modified, is expressed by us when we say that a true style must be unique, if we understand the author by the phrase "a true style», which is completely adequate expression in the language of a writer's general mode of feelings.

In discussing the problem of individual style let us make it clear from the outset that the problem itself is a common ground for Psychology. However, as much as the language is the only media to accommodate poetic messages, it is necessary to go at some length into the domain of the author's individual style, it has been testing ground for different language means.

(C) Mykhalchuk Nataliia, Koval Iryna DOI (article): https://doi.org/10.32626/2227-6246.2021-54.93-115 
DOI: https://doi.org/10.32626/2227-6246.2021-54

2021. випуск 54

The individual style of the author is frequently identified with a general term «style». But as it has already been pointed out, style is a much broader notion. The individual style of the author is only one of the applications of a general term «the author's style». The analysis of the author's language seems to be the most important procedure in estimating his/her individual style or manner of writing. This is obviously not only because the language is the only means available to convey the author's ideas to the reader in precisely the way he/she intends, but also because writers unwittingly contribute greatly to establishing the norms of the literary language of a given period. In order to compel the language to serve the author's purpose, the writer draws on its potential resources in a way to be different from what we see in his/her ordinary speech.

To summarise all this information it should be said that the definitions of style are numerous and too heterogeneous to fall under one more or less satisfactory unified notion. All of these diversities in the understanding of the word «style» stem focus on its ambiguity. At the same time all of them point out to some integral significance, such as the style is a set by its characteristics by which we distinguish one author from another one or from other members of one subclass, from the members of other subclasses, all of whom are the members of the same general class.

In our research we will examine the most important features of Charles Dickens' individual style of writing and the characteristics of students' understanding of Charles Dickens, the effect produced by the language expressive means and stylistic devices in the authors' texts of students. It's the aim of our research.

\section{Methods of the research}

The following theoretical methods of the research were used to solve the tasks formulated in the article: a categorical method, structural and functional methods, the methods of C Mykhalchuk Nataliia, Koval Iryna

DOI (article): https://doi.org/10.32626/2227-6246.2021-54.93-115 
the analysis, systematization, modeling, generalization. The experimental method is the method of interview.

The participants of our research were 32 students of the $2^{\text {nd }}$ course of the Philological faculty of Rivne State University of the Humanities. The experiment lasted during 2020-2021 years.

\section{Results and their discussion}

So, students have to analyze dark humour, periphrasis, contrast, slang and other devices as important means in expressing the author's concepts in "Oliver Twist». So, in our research we'll propose pupils the procedures of stylistic analysis of novels which the teacher may use at the lessons. This brief outline of the most important characteristic features of language styles and their variants will show that out of the number of features which are easily discernible in each of the styles, some should be considered primary and others secondary; some obligatory, others - optional; some constant, others - transitory.

So, students proposed such kind of analyses of the novel.

Ivan L.: "Speaking about the stylistic features of the novel «Oliver Twist» I'd like to say that there are many examples of dark humour in it. This kind of humour helps to sharpen the desperate sufferings of Oliver and other characters. The author gives us a great opportunity to laugh, but the sadness remains in the particular contexts. It is a special feature of dark humour.

Sharp irony also gives an effect of dark humour. Dickens uses irony in «Oliver Twist» to satirize the various institutions (the parish workhouse system, the justice system, the poor laws, etc.) that he thought were inhumane and unjust. For example, at the beginning of Chapter 5, the narrator satirizes Mr. Bumble by sarcastically calling himself "a humble author" in comparison to be "so mighty a personage as a beadle». In fact a beadle wasn't at all that important person, so Dickens is

(C) Mykhalchuk Nataliia, Koval Iryna DOI (article): https://doi.org/10.32626/2227-6246.2021-54.93-115 
DOI: https://doi.org/10.32626/2227-6246.2021-54

2021. випуск 54

clearly being ironic. The effect of satire is to show how pompous and self-satisfied as many officials like Mr. Bumble were.

The novel «Oliver Twist» abounds in dark humour: from $\mathrm{Mr}$. Bumble and Mr. Sowerberry laughing about the abundance of small children's coffins to Dickens's mocking the seriousness and puffery of the members of the parish board, to his exposure of the cowardice and avarice of Noah and Charlotte, to the capering of Arthur Dodger when he is put on trial. We should analyse some other examples of dark humour in the novel to prove this.

«Oliver bowed low by the direction of the beadle, and was then hurried away to a large ward: where, on a rough, hard bed, he sobbed himself to sleep. What a noble illustration of the tender laws of England! They let the paupers go to sleep!» (Dickens, 1991: 34). "The bowls never wanted washing. The boys polished them with their spoons till they shone again; and then they had performed this operation (which never took very long, the spoons being nearly as large as the bowls)» (Dickens, 1991: 38). "Occasionally, when there was some more than usually interesting inquest upon a parish child who had been overlooked in turning up a bedstead, or inadvertently scalded to death when there happened to be a washing - though the latter accident was very scarce, anything approaching to a washing being of rare occurrence in the farm - the jury would take it into their heads to ask troublesome questions, or the parishioners would rebelliously affix their signatures to a remonstrance» (Dickens, 1991: 43). By using dark humour the author not only laughs, but expresses compassion to Oliver. At the same time he emphasises the unfair and cruel attitude to the orphans. In the first example we see sarcasm as a stylistic device.

«I, Mrs. Mann. We name our fondlings in the alphabetical order. The last was S, - Swubble, I named him. This was a T, - Twist, I named (r) him. The next one as comes will be Unwin, and the next Vilkins. I have got names ready made to (c) Mykhalchuk Nataliia, Koval Iryna

DOI (article): https://doi.org/10.32626/2227-6246.2021-54.93-115 
the end of the alphabet, and all the way through it again, when we come to $\mathrm{Z}$ » (Dickens, 1991: 25). In this case we can see the procedure of naming orphans. It looks very cynical. In this way Dickens convicted such a treatment of children.

"But the magistrate was half blind and half childish, so he couldn't reasonably be expected to discern what other people did» (Dickens, 1991: 47). Here Dickens criticises the justice system of England and calls a judge «half blind and half childish».

«Let him alone!» said Noah. "Why everybody lets him alone enough, for the matter of that. Neither his father nor his mother will ever interfere with him. All his relations let him have his own way pretty well. Eh, Charlotte? He! he! he!» (Dickens, 1991: 56). This example shows us the drawbacks of the English society and its cruelty (Noah jeers at Oliver being the orphan).

Dickens has a taste for black jokes, often of a crude kind; but he also has a taste for jokes which show real social illnesses and in this way he makes his reader laugh and cry at the same time. In "Oliver Twist», where pathos and humour blend uncomfortably and powerfully, in the workhouse, the undertaker's, and the thieves' den, he describes the intermingling of genres in his simile of streaky bacon, a nicely judged placing of serious tenor in comic vehicle:

"It is the custom of the stage, in all good murderous melodramas, to present the tragic and the comic scenes, in as regular alternation as the layers of red and white in a side of streaky bacon» (Dickens, 1991: 44).

There are some examples of pun (or "a play on words»), which produces a comic effect:

«Bow to the board», said Bumble; Oliver brushed away two or three tears that were lingering in his eyes and seeing no board but the table, fortunately bowed to that» (Dickens, 1991: 38). "A play on words» is built by two homonyms. The first word «board» means the members of the workhouse board

(C) Mykhalchuk Nataliia, Koval Iryna DOI (article): https://doi.org/10.32626/2227-6246.2021-54.93-115 
DOI: https://doi.org/10.32626/2227-6246.2021-54

2021. випУСК 54

and the second one - a classroom board. This example of homonymy is created as a result of breaking up the ambiguity».

The next analysis of the novel "The Adventures of Oliver Twist» by Ch. Dickens was done by Olga E.

Olga E.: «Dickens uses «flat» characters: his heroes don't tend to grow or change over the course book. Oliver, who begins well, stays good, and he never wises up; never once he shows any awareness that the thieves are truly evil or any real disgust at Fagin's life. He is afraid of the thieves because they may hurt him, but not because they're twisted and corrupted souls. Fagin, who begins evil, stays that way. Many of the characters are easily marked by certain "tags" of behaviour or voice: Mr. Grimwig habitually thumps his cane on the ground and asserts: «I'll eat my head!» (Dickens, 1991: 39) Fagin is always out for money; Mr. Brownlow is steadfastly good; Monks is obsessively evil. Mr. Bumble is consistently pompous and shallow, and Noah Claypole remains a coward and a bully throughout the book.

In such a way I'll state: "The characters in "Oliver Twist» are caricatures given to us as pure good or pure evil... I don't know which are worse. Rose Maily is so sickeningly sweet and good. So is Oliver Twist for that matter. Reading about either of them is like eating French toast with gobs of maple syrup but leaving out the French toast. Just spoon that maple syrup straight into your mouth». Beauty and goodness are equivalent to each other. Rose Maily is as pretty as a picture, even as two pictures, and so is our pansy good, two shoes of Oliver Twist. Perfection is too weak as any word for them. Meanwhile, the Jew is a despicably ugly character, both physically and morally. And when Oliver wakes up and looks out the window he spies the Jew, and he wakes up screaming: "The Jew! The Jew!» (Dickens, 1991: 72)

At the end of the novel Oliver's entry into a loving surrogate family is made even more idyllic by the fact that he inherits a great deal of money».

(C) Mykhalchuk Nataliia, Koval Iryna

DOI (article): https://doi.org/10.32626/2227-6246.2021-54.93-115 
We've to note that every novel is a cultural phenomenon. The global question is what makes a novel "cultural» is that it is not the speech information itself that describes the "passive and voiceless» object of a particular study, but the fact that the novel is the text of another, dissimilar to our consciousness. When we are dealing with the author, with his personal worldview and the meaning that appears in the text is relevant. There is nothing in the culture but meanings and means of their transmission. The novel is a phenomenon of a certain culture and, as a result, can be considered as a «meaningful world». During the «meeting» of the person with the work, our own understanding of life will be included into the situation of cultural communication with the author. The personal meanings of the recipient and the author's one are always dissimilar, even completely dissimilar, sometimes strikingly different from each other. This, of course, in some a way complicates the process of understanding a novel, but this discrepancy influences on its understanding. We consider a novel to be a piece of another consciousness, the understanding of which inevitably turns into a dialogue, a «meeting in a meaningful world».

We recognize the main characteristic of a novel as its dialogic nature, emphasizing two-dimensional existence of the text. We think that each text has its subject, the author. Also there is another plan of the text - another subject, which reproduces someone another text and creates so called outlined text (commented, evaluated, denied). We'd like to emphasize the complexity of the relationships between these two plans, because they create a "meeting" of two texts - the completed structure and some text that can be created; it is a meeting of two consciousnesses, two authors. That is why, the dialogical nature of a novel directs the author's position, the author's «voice» to the reader, who agrees or disagrees, asks, answers or not, also denies.

(C) Mykhalchuk Nataliia, Koval Iryna

DOI (article): https://doi.org/10.32626/2227-6246.2021-54.93-115 


\section{Conclusions}

Therefore, we can be argue that a novel is understood as the implementation of a system, as a lexical and syntactical formation, which contains signs of natural language, which has been defined by the author with the help of boundaries and internal semiotic organization. The latter at the syntagmatic level turns the text into a structural whole. The basis of a novel is its output in other texts, pieces of art, the presence of such characteristics as communicative orientation.

We also believe that any novel is dialogical in its internal structure, because it contains both real and hidden appeals to some authors, directed against the views of other authors. If a non-dialogical text is possible it would be meaningless or would take on a form that can be given any meaning that is practically the same.

\section{Literature}

Гончарук Н., Онуфрієва Л. Психологічний аналіз рівнів побудови комунікативних дій. Psycholinguistics. Психолінгвістика. Психолингвистика, 2018, 24 (1), 97-117. DOI 10.31470/2309-1797-2018-241-97-117.

Максименко С., Ткач Б., Литвинчук Л., Онуфрієва Л. Нейропсихолінгвістичне дослідження політичних гасел із зовнішньої реклами. Psycholinguistics. Психолінгвістика. Психолингвистика, 2019, 26 (1), 246-264. DOI 10.31470/2309-1797-2019-26-1-246-264.

URL : https://psycholing-journal.com/index.php/journal/article/ view/715.

Терновик Н., Сімко А. Художня література як засіб формування підлітка як суб’єкта пізнавальної діяльності. Збірник наукових праць «Проблеми сучасної психологї̈, 2020, 49, 322-341. DOI https:// doi.org/10.32626/2227-6246.2020-49.322-341.

Тлумачний словник «Multitran». 2021. URL : https://www.multitran. com.

Brédart, S. Word interruption in self-repairing. Journal of Psycholinguistic Research, 1991, 20, 123-137. URL : https://doi.org/10.1007/ bf01067879.

Cilibrasi, L., Stojanovik, V., Riddell, P., \& Saddy, D. Sensitivity to Inflectional Morphemes in the Absence of Meaning: Evidence from a Novel

(C) Mykhalchuk Nataliia, Koval Iryna

DOI (article): https://doi.org/10.32626/2227-6246.2021-54.93-115 
DOI: https://doi.org/10.32626/2227-6246.2021-54 2021. ВИПУСК 54

Task. Journal of Psycholinguist Research, 2019, 48, 747-767. URL : https://doi.org/10.1007/s10936-019-09629-y.

Crookes, G. Planning and interlanguage variation. Studies in Second Language Acquisition, 1989, 11, 367-383. URL : https://doi.org/ 10.1017/s0272263100008391.

Dickens, Charles. The Adventures of Oliver Twist. London : Random House, 1991. 334 p.

Mykhalchuk, N., \& Bihunova, S. The verbalization of the concept of «fear» in English and Ukrainian phraseological units. Cognitive Studies Études cognitives, 2019, 19, 11. Варшава (Польща). URL : https:// doi.org/10.11649/cs.2043.

Mykhalchuk, N., \& Ivashkevych, E. Psycholinguistic Characteristics of Secondary Predication in Determining the Construction of a Peculiar Picture of the World of a Reader. Psycholinguistics. Psykholinhvistyka. Psiholingvistika, 2019, 25 (1), 215-231. DOI 10.31470/2309. 1797-2019-25-1-215-231.

\section{References}

Honcharuk, N., \& Onufriieva, L. (2018). Psykholohichnyi analiz rivniv pobudovy komunikatyvnykh dii [Psychological analysis of the levels of construction of communicative actions]. Psykholinhvistyka. Psikholingvistika. Psycholinguistics - Psycholinguistics. Psycholinguistics. Psycholinguistics, 24 (1), 97-117. Retrieved from https://doi. org/10.31470/2309-1797-2018-24-1-97-117 [in Ukrainian].

Maksymenko, S., Tkach, B., Lytvynchuk, L., \& Onufriieva, L. (2019). Neiropsykholinhvistychne doslidzhennia politychnykh hasel iz zovnishnoi reklamy [A neuropsycholinguistic research of political slogans from outdoor advertising]. Psykholinhvistyka. Psikholingvistika. Psycholinguistics - Psycholinguistics. Psycholinguistics. Psycholinguistics, 26 (1), 246-264. Retrieved from https://psycholing-journal. com/index.php/journal/article/view/715 [in Ukrainian].

Ternovyk, N., \& Simko, A. (2020). Khudozhnia literatura yak zasib formuvannia pidlitka yak subiekta piznavalnoi diialnosti [Fiction as a means of forming a teenager as a subject of cognitive activity]. Zbirnyk naukovykh prats "Problemy suchasnoi psykholohii»-Collection of research papers "Problems of modern Psychology», 49, 322341. Retrieved from https://doi.org/10.32626/2227-6246.2020-49. 322-341 [in Ukrainian].

Tlumachnyi slovnyk «Multitran» [Dictionary «Multitran»] (2021). Retrieved from http://www.multitran.com.

(c) Mykhalchuk Nataliia, Koval Iryna

DOI (article): https://doi.org/10.32626/2227-6246.2021-54.93-115 
Brédart, S. (1991). Word interruption in self-repairing. Journal of Psycholinguistic Research, 20, 123-137. Retrieved from https://doi.org/ $10.1007 /$ bf01067879.

Cilibrasi, L., Stojanovik, V., Riddell, P., \& Saddy, D. (2019). Sensitivity to Inflectional Morphemes in the Absence of Meaning: Evidence from a Novel Task. Journal of Psycholinguist Research, 48, 747-767. Retrieved from https://doi.org/10.1007/s10936-019-09629-y.

Crookes, G. (1989). Planning and interlanguage variation. Studies in Second Language Acquisition, 11, 367-383. Retrieved from https:// doi.org/10.1017/s0272263100008391.

Dickens, Charles (1991). The Adventures of Oliver Twist. London : Random House.

Mykhalchuk, N., \& Bihunova, S. (2019). The verbalization of the concept of "fear» in English and Ukrainian phraseological units. Cognitive Studies $\mid$ Études cognitives, 19, 11. Warsaw (Poland). Retrieved from https://doi.org/10.11649/cs.2043.

Mykhalchuk, N., \& Ivashkevych, E. (2019). Psycholinguistic Characteristics of Secondary Predication in Determining the Construction of a Peculiar Picture of the World of a Reader. Psykholinhvistyka. Psikholingvistika. Psycholinguistics - Psycholinguistics. Psycholinguistics. Psycholinguistics, 25 (1), 215-231. Retrieved from https://doi. org/10.31470/2309-1797-2019-25-1-215-231.

Михальчук Наталія, Коваль Ірина. Психологічні шляхи розуміння текстової реальності

\section{АНОТАЦІЯ}

Мета статmі - проаналізувати найважливіші риси індивідуального стилю написання тексту Чарльзом Діккенсом, особливості розуміння цього автора студентами, а також психологічні шляхи текстової реальності, викликані мовними експресивними й стилістичними засобами в авторських текстах студентів.

Для розв'язання поставлених у роботі завдань використано такі теоретичні методи дослідження: категоріальний, структурно-функціональний, аналіз, систематизація, моделювання, узагальнення. У якості експериментального методу нами використано метод інтерв'ю.

Результати дослідження. Зазначено, що кожен літературний твір $\epsilon$ феноменом культури. "Культурним» літературний твір робить саме те, що перед нами - не власне мовленнєва інформація, в межах якої опи(c) Mykhalchuk Nataliia, Koval Iryna

DOI (article): https://doi.org/10.32626/2227-6246.2021-54.93-115 
саний «пасивний і безголосий» об'єкт певного дослідження, а те, що твір $\epsilon$ витвором іншої, неподібної до нашої свідомості. Так, ми маємо справу з автором, із його особистісним світоглядом і світосприйняттям, і тим смислом, який у тексті постає як актуальний. Підкреслено, що у культурі не існує нічого, крім смислів і засобів їх передачі. Твір - феномен певної культури і, як наслідок, може розглядатися як "осмислений світ». Під час "зустрічі» з твором наше власне осмислення буття включатиметься в ситуацію культурного спілкування з автором. Особистісні смисли реципієнта й авторські - завжди не схожі, навіть зовсім не подібні, іноді вражаюче відмінні один від одного. Це, безперечно, певним чином ускладнює процес осмислення літературного твору, але ия розбіжність і сприяє його розумінню. Ми вважаємо літературний твір витвором іншої свідомості, розуміння якого неминуче перетворюється на діалог, на «зустріч в осмисленому світі».

Основною характеристикою літературного твору визначено його діалогічність, акцентуючи увагу на двоплановості існування тексту. Зазначено, що будь-який текст має свого суб'єкта, автора. Існує й інший план - інший суб'єкт, який відтворює чужий текст і створює окреслений текст (коментований, оцінювальний, заперечувальний). Наголошено на складність взаємовідношення цих двох планів, адже вони створюють собою зустріч двох текстів - завершеного й того, що створюється; че - зустріч двох свідомостей, двох авторів. Тобто, діалогічна природа літературного твору спрямовує позицію автора, авторський «голос» до чита4а, який погоджується або ні, запитує, відповідає або ні, заперечує тощо.

Висновки. Наголошено, що літературний твір розглядається як реалізація певної системи, як матеріальне утворення, що містить у собі знаки природної мови, що має визначені автором межі й внутрішню семіотичну організацію. Остання на синтагматичному рівні перетворює текст у структурне ціле. Основою літературного твору вважається його вихід в інші твори, тобто наявність такої характеристики, як комунікативна спрямованість.

Зазначено, що будь-який літературний твір за своєю внутрішньою структурою є діалогічним, тому що вміщує як реальні, так і приховані апеляції до одних авторів, спрямовані проти поглядів інших авторів. Доведено, що якби і був можливим недіалогічний твір, то він був би позбавлений змісту або набув такого вигляду, якому можна надати будь-якого сенсу, що, практично, одне й те ж саме.

(C) Mykhalchuk Nataliia, Koval Iryna

DOI (article): https://doi.org/10.32626/2227-6246.2021-54.93-115 
DOI: https://doi.org/10.32626/2227-6246.2021-54

2021. випУск 54

Ключові слова: розуміння текстової реальності, діалогічний текст, недіалогічний текст, індивідуальний стиль написання, комунікативна орієнтація, внутрішня семіотична організація, культурне квазіспілкування з автором твору.

\section{Михальчук Наталия, Коваль Ирина. Психологические пути понимания текстовой реальности}

\section{АННОТАЦИЯ}

Цель статьи - проанализировать важнейшие черты индивидуального стиля написания текста Чарльзом Диккенсом, особенности понимания данного автора студентами, а также психологические пути текстовой реальности, вызванные языковыми экспрессивными и стилистическими средствами в авторских текстах студентов.

Для решения поставленных в работе задач использованы следующие теоретические методы исследования: категориальный, структурно-функциональный, анализ, систематизация, моделирование, обобщение. В качестве экспериментального метода нами использован метод интервью.

Результаты исследования. Указано, что каждое литературное произведение является френоменом культуры. "Культурным» литературное произведение делает именно то, что перед нами - не собственно речевая информация, в рамках которой описан «пассивный и безголосый» объект определенного исследования, а то, что произведение является произведением другого, похожего на наше сознания. Мы имели дело с автором, с его личным мировоззрением и мировосприятием, а также тем смыслом, который в тексте представлен как актуальный. Отмечено, что в культуре не существует ничего, кроме смыслов и средств их передачи. Художественное произведение является феноменом определенной культуры и, как результат, может рассматриваться как некий «осмысленный мир». Во время "встречи» с произведением наше собственное осмысление бытия включено в ситуацию культурного общения с автором. Личностные смыслы реципиента и автора - всегда похожи, даже когда они совсем не похожи по своему содержанию, иногда являются поразительно отличными друг от друга. Это, безусловно, определенным образом затрудняет процесс осмысления литературного произведения, но это расхождение и способствует его пониманию. Мы считаем литератур(c) Mykhalchuk Nataliia, Koval Iryna

DOI (article): https://doi.org/10.32626/2227-6246.2021-54.93-115 http://journals.uran.ua/index.php/2227-6246 
ное произведение произведением другого сознания, понимание которого неизбежно превращается в диалог, в «встречу в осмысленном мире».

Основной характеристикой литературного произведения считается его диалогичность, которая акцентирует внимание на двуплановости существования текста. Отмечено, что любой текст имеет своего субъекта, автора. Существует и другой план-другой субъект, который воспроизводит чужой текст и создает очерченный текст (комментируемый, оценочный, требующий возражения). Отмечены сложности во взаимоотношениях этих двух планов, ведь они создают собой встречу двух текстов - завершенного и того, который создается; это - встреча двух сознаний, двух авторов. То есть, диалогическая природа литературного произведения направляет позиции автора, авторский «голос» к читателю, который соглашается или нет, спрашивает, отвечает или нет, отрицает информацию.

Выводы. Литературное произведение рассматривается как реализация определенной системы, как материальное образование, которое содержит в своей структуре знаки естественного языка, имеет определенные автором границы и внутреннюю семиотическую организацию. Последняя на синтагматическом уровне превращает текст в структурное целое. Основой литературного произведения считается его выход в другие произведения, то есть наличие такой характеристики, как коммуникативная направленность.

Указано, что любое литературное произведение по своей внутренней структуре является диалогическим, поскольку содержит как реальные, так и скрытые апелляции к одним авторам, направленные против взглядов других авторов. Доказано, что если бы и была возможность создания недиалогического произведения, то оно было бы лишено смысла или приобрело такой вид, которому можно придать любой смысл, что практически одно и то же.

Ключевые слова: понимание текстовой реальности, диалогический текст, недиалогический текст, индивидуальный стиль написания, коммуникативная ориентация, внутренняя семиотическая организация, культурное квазиобщение с автором произведения.

Original manuscript received September 09, 2021 Revised manuscript accepted October 14, 2021

(c) Mykhalchuk Nataliia, Koval Iryna DOI (article): https://doi.org/10.32626/2227-6246.2021-54.93-115 